\title{
Performance of Native Florida Plants under North Florida Conditions 1
}

Jeffrey G. Norcini and James H. Aldrich ${ }^{2}$

1. This document is ENH1074, one of a series of the Environmental Horticulture Department, Florida Cooperative Extension Service, Institute of Food and Agricultural Sciences, University of Florida. Original publication date November, 2007. Visit the EDIS Web Site at http://edis.ifas.ufl.edu.

2. Jeffrey G. Norcini, Associate Professor, native wildflower specialist and James H. Aldrich, Senior Biological Scientist, North Florida. Research \& Education Center, Quincy, FL 32351.

The Institute of Food and Agricultural Sciences (IFAS) is an Equal Opportunity Institution authorized to provide research, educational information and other services only to individuals and institutions that function with non-discrimination with respect to race, creed, color, religion, age, disability, sex, sexual orientation, marital status, national origin, political opinions or affiliations. U.S. Department of Agriculture, Cooperative Extension Service, University of Florida, IFAS, Florida A. \& M. University Cooperative Extension Program, and Boards of County Commissioners Cooperating. Larry Arrington, Dean 


\title{
Performance of Native Florida Plants under North Florida Conditions ${ }^{1}$
}

\author{
Jeffrey G. Norcini and James H. Aldrich ${ }^{2}$
}

Demand for native wildflowers and grasses has increased over the past 15-20 years as part of the surge in interest in use of native species, especially native plants that are adapted to local or regional conditions. Such native plants often are referred to as ecotypes. Since the landscape market for regional ecotypes of wildflowers is relatively new, few native wildflowers from different regional seed sources have been formally evaluated for their suitability under landscape conditions.

Determining which native species are suitable for landscapes is important in order to facilitate commercial production. In 2006, we conducted a landscape evaluation of native wildflowers (plus one native grass) under north Florida conditions. Seeds were derived mainly from naturally-occurring populations in Florida.

Species are listed in alphabetical order by scientific name, with the common name in parentheses. These names, as well as the species' distribution within Florida, were derived from the Florida Atlas of Vascular Plants (http://plantatlas.usf.edu).

Natural habitat information is presented as a guide to selecting planting sites. All species are considered full sun plants in their natural habitat, although many will also thrive under high pine shade or along woodland edges that receive several hours of direct sun. Some species adapted to moist or wet conditions are included because it's been our experience that such species perform well under garden conditions as long as the soil does not dry out.

Plant Culture. Seeds of most species were derived directly or indirectly from naturally occurring populations in Florida; seeds of two species were derived from Alabama or Georgia (Table 1). In January or February 2006, seeds were sown in Metro-Mix ${ }^{\circledR} 200$ (Scotts-Sierra Horticultural Products Co., Marysville, $\mathrm{OH}$ ) and placed on propagation mats (Pro-Grow Supply Corp., Brookfield, WI) in a glasshouse. The propagation mats

1. This document is ENH1074, one of a series of the Environmental Horticulture Department, Florida Cooperative Extension Service, Institute of Food and Agricultural Sciences, University of Florida. Original publication date November 2007. Visit the EDIS Web Site at http://edis.ifas.ufl.edu.

2. Associate Professor, native wildflower specialist, and Senior Biological Scientist, North Florida. Research \& Education Center, Quincy, FL 32351. The use of trade names in this publication is solely for the purpose of providing specific information. UF/IFAS does not guarantee or warranty the products named, and references to them in this publication named, and references to them in this publication does not signify our approval to the exclusion of other products of suitable composition.

The Institute of Food and Agricultural Sciences (IFAS) is an Equal Opportunity Institution authorized to provide research, educational information and other services only to individuals and institutions that function with non-discrimination with respect to race, creed, color, religion, age, disability, sex, sexual orientation, marital status, national origin, political opinions or affiliations. U.S. Department of Agriculture, Cooperative Extension Service, University of Florida, IFAS, Florida A. \& M. University Cooperative Extension Program, and Boards of County Commissioners Cooperating. Larry Arrington, Dean. 
maintained the medium temperature between 60 and $85^{\circ} \mathrm{F}$. Ambient air temperature fluctuated between 50 and $100^{\circ} \mathrm{F}$. Daily irrigation was applied via a mist system that completely saturated the medium. Approximately 7 to 10 days after seeds were sown, emerged seedlings were fertigated weekly with 100 ppm N (Scotts Miracle-Gro® 15-3015 with minors; Scotts Miracle-Gro Products, Inc., Marysville, $\mathrm{OH}$ ). One month after the seeds were sown, seedlings were transplanted into individual cells of 1204 inserts (Cassco, Montgomery, AL) in $10 \times 20$-inch flats. Seedlings were fertigated for another month as described previously. Just prior to transplanting into the evaluation garden, plants were fertigated with 100 ppm N with Scotts Miracle-Gro ${ }^{\circledR}$ 10-52-10 with minors (The Scotts Miracle-Gro Co., Marysville, $\mathrm{OH}$ ).

The evaluation garden was in full sun and covered with black woven landscape fabric. Drip tape irrigation (RO-DRIP ${ }^{\circledR}$; 8-inch spacing $40 \mathrm{GPH} / 100 \mathrm{ft}$ flow rate; Roberts Irrigation Products, Inc., San Marcos, CA) was laid underneath the fabric adjacent to each row. Seedlings were transplanted into 4-inch rows (10-ft plot per species) as follows: Ipomopsis rubra -8 inches on center; Coreopsis nudata, Liatris gracilis, Mimosa strigillosa, and Flaveria linearis - 12 inches on center; all other species were planted 18 inches on center. Plots were not replicated. Transplanted seedlings were fertilized with 15-9-12 Osmocote Plus Southern (12-14 month formulation; Scotts) at a rate of $2 \mathrm{lb} / 100 \mathrm{ft}^{2}$. Pine needle mulch was placed around the transplanted seedlings. Plants were irrigated at transplanting, twice per week for 1 month, and then periodically thereafter during periods of drought. Flowering plants were not deadheaded.

Rudbeckia mollis seeds were sown in late fall of 2005 with culture similar to that described above. About December 2005, seedlings were transplanted into 1204 inserts and remained in the glasshouse until early February 2006 when the plants were moved under a shadehouse (30\% light exclusion; daily irrigation) until they were transplanted in the garden.

Evaluation. Weekly from April 18 to December 19, 2006, three evaluators visually rated each species (whole plot basis) for overall appearance (1=poor, 2=fair, $3=$ good, $4=$ very good, and $5=e x c e l l e n t)$, notable insect or disease damage, and the presence of 5 or more open flowers per plant. Also, dates of the first fully opened flower and peak bloom (visually estimated) were recorded. Total height and width, height and width of "vegetative growth only", and diameters of 5 fully opened flowers were recorded at peak bloom. Monthly temperature and rainfall data during the evaluation were recorded (Table 2). Insects and diseases are noted only if damage was apparent. Visual ratings of the evaluators were averaged and are graphically presented for each species. 


\section{Coreopsis floridana (Florida tickseed)}

\section{Description - Natural Habitat}

Florida tickseed is a short-lived perennial to perennial. Plants have showy, deep yellow ray flowers (petals) with dark reddish purple disc flowers, and thick leathery leaves borne on stout, succulent stems. Flower buds and the immature seedheads are burgundy to purple. Florida tickseed is the only tickseed endemic to Florida. While found throughout most of the state, this wetland species of flatwoods, bogs, prairies, and roadsides occurs mainly in the peninsula.

\section{Landscape Performance}

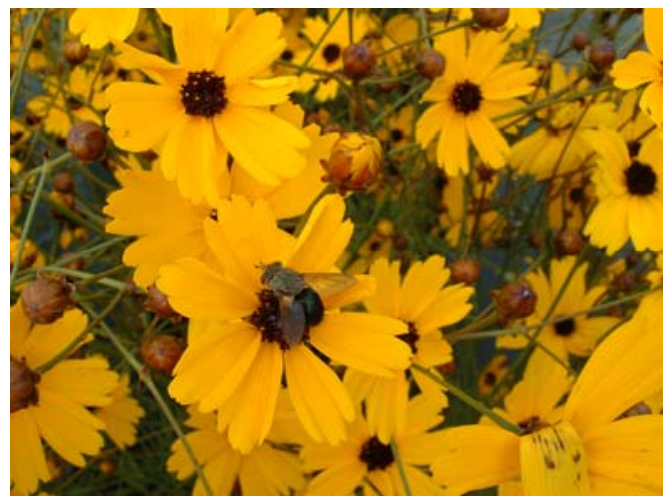

The plants were visually appealing from late June until mid-August, when deer started to feed on them (Fig. 2). Deer ate plants to the soil line. Five or more flowers per plant occurred on August 8. (Table 3). Interestingly, container-grown plants and those in seed production plots at the NFREC typically begin to flower in late October. A scale infestation was observed on August 8 but deer feeding precluded identification of the scale. No measurements were recorded because the plants did not reach peak bloom due to deer browsing.

Plants persisted to winter but most did not reemerge the following spring.

Figure 2. Overall appearance rating ( $1=$ poor to $5=$ excellent $)$ of Coreopsis floridana from April 18 to December 19, 2006.

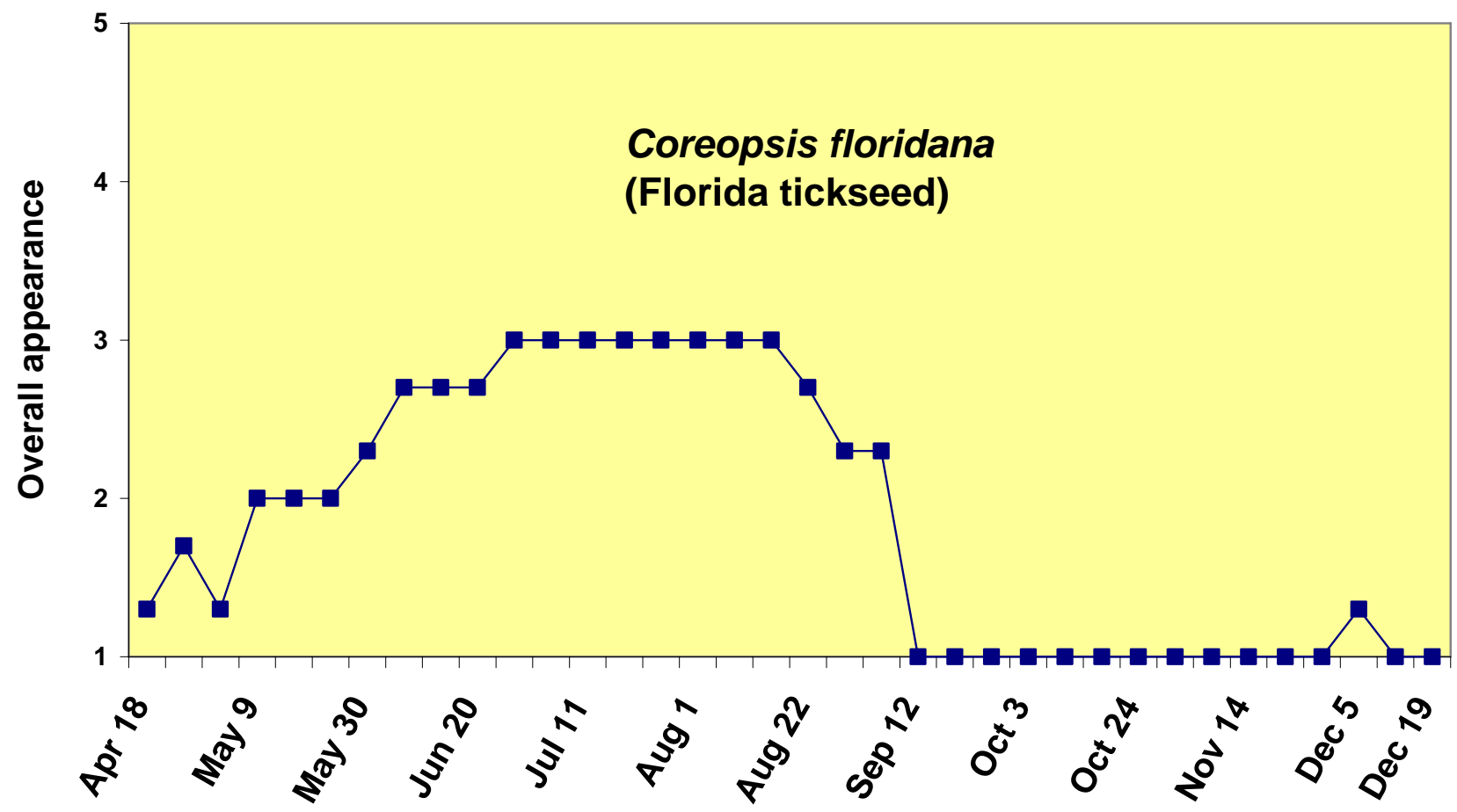




\section{Coreopsis grandiflora (largeflower tickseed)}

\section{Description - Natural Habitat}

Largeflower tickseed is a short-lived perennial to perennial. Both the disc flowers and ray flowers are yellow. In Florida, it has been documented in only two counties - Liberty and Lafayette. Flowering in north Florida occurs in July. This species occurs in sites with partial shade to full sun and well-drained soil.

\section{Landscape Performance}

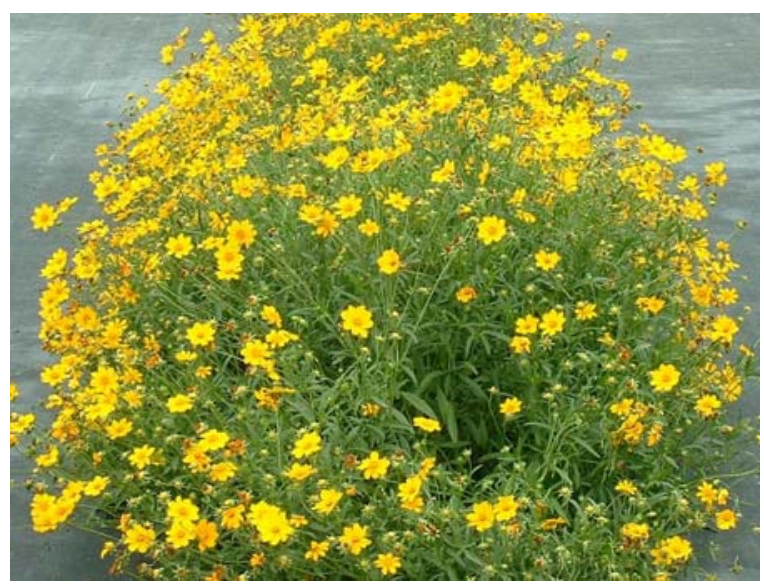

Peak performance of largeflower tickseed was in early June (Fig. 3). Plants were rated very good to good from mid-May to midSeptember. Five or more flowers per plant occurred from May 30 to December 5. An unidentified leaf spot was observed sporadically during the entire evaluation period, and there was slight damage from chewing insects and leaf miners.

Figure 3. Overall appearance rating ( $1=$ poor to $5=$ excellent) of Coreopsis grandiflora from April 18 to December 19, 2006.

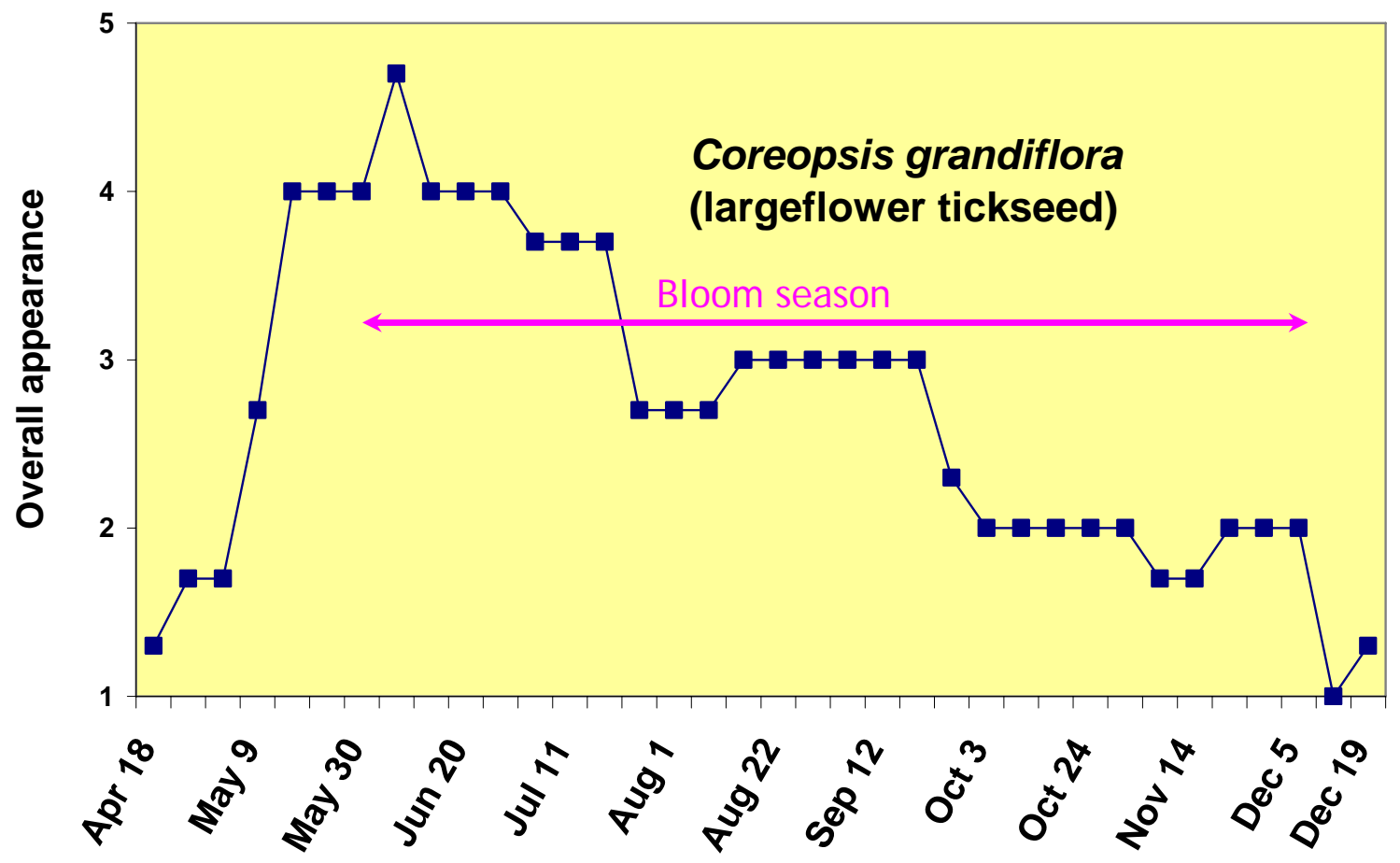




\section{Coreopsis lanceolata (lanceleaf tickseed)}

\section{Description - Natural Habitat}

Lanceleaf tickseed is a clump-forming, short-lived, evergreen to semi-evergreen perennial. It has lance-shaped leaves principally found at the base of the plant. The main flowering season in north Florida is late March and into May. Both ray flowers and disc flowers are yellow. It primarily occurs in the panhandle and northern peninsular Florida. Lanceleaf tickseed prefers full sun in a dry to slightly moist but well-drained soil. It can tolerate light shade and occasional freezes to the mid-20s.

\section{Landscape Performance}

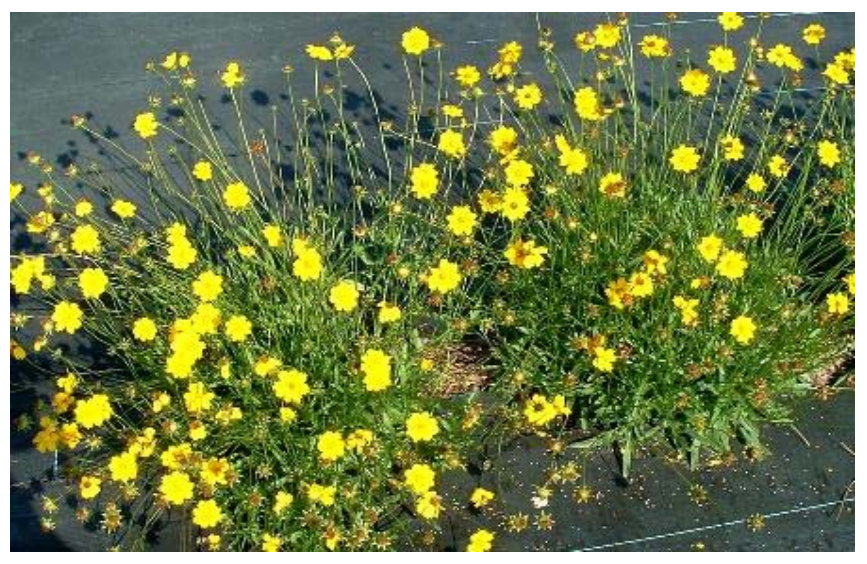

Peak performance was from early May to early June, with good overall appearance until about mid-September and fair appearance until early December (Fig. 4). Flowering commenced in late April and peaked in late May, but there were at least 5 open flowers per plant until December (Table 3). There was slight insect damage from chewing insects and thrips. Slight disease damage (leaf spot) was observed starting in mid-October.

Figure 4. Rating of overall appearance $(1=$ poor to $5=$ excellent $)$ of Coreopsis lanceolata from April 18 to December 19, 2006.

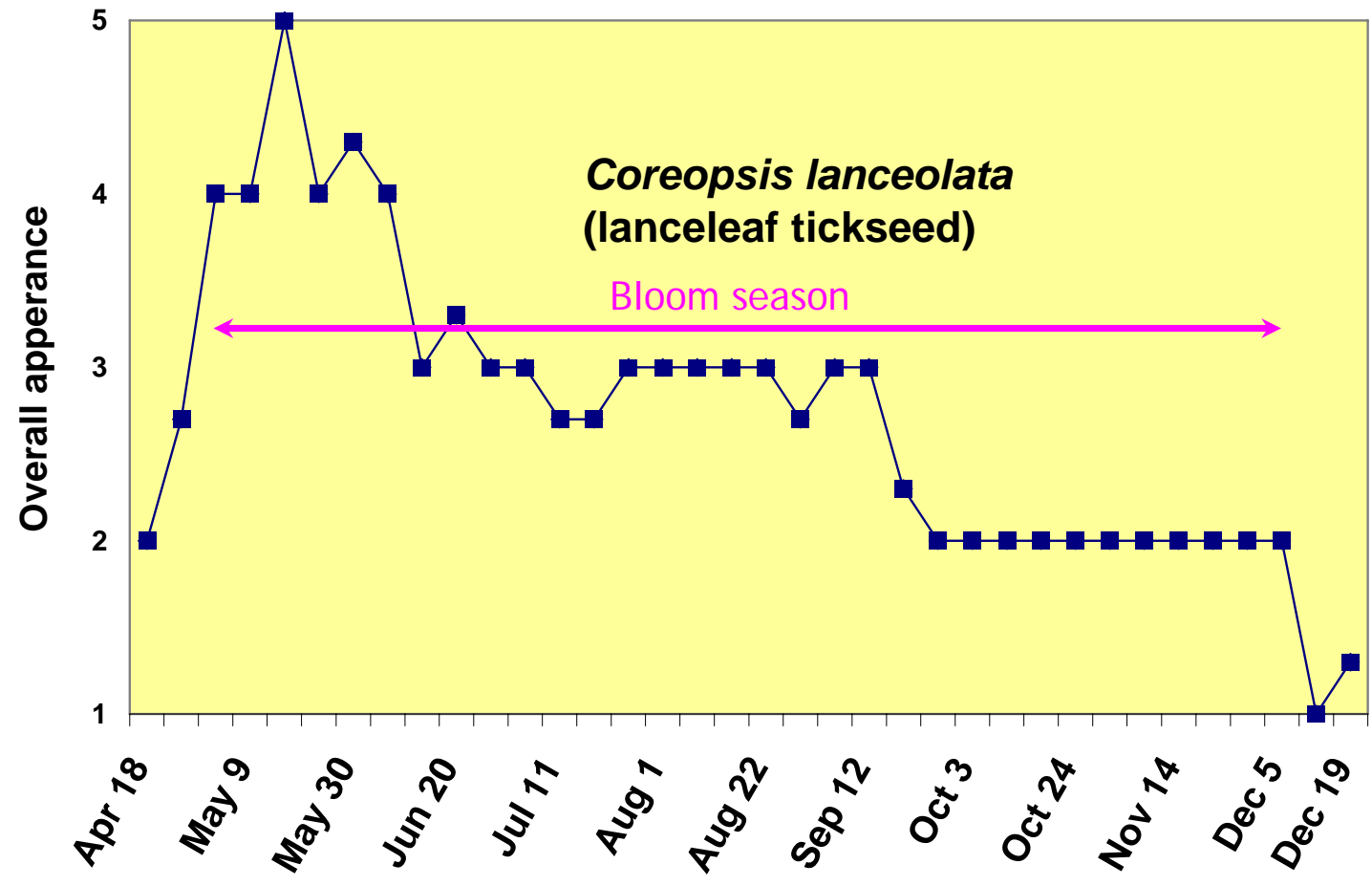


Coreopsis leavenworthii (Leavenworth's tickseed)

Description - Natural Habitat

Leavenworth's tickseed occurs throughout Florida and is most often found growing in sunny sites with slightly moist to moist soils. In northern Florida it tends to be an annual, but it is a short-lived perennial farther south. The showy ray flowers are yellow, and disc flowers are dark brown. Flowering season in north Florida is mainly from late spring through late summer.

\section{Landscape Performance}

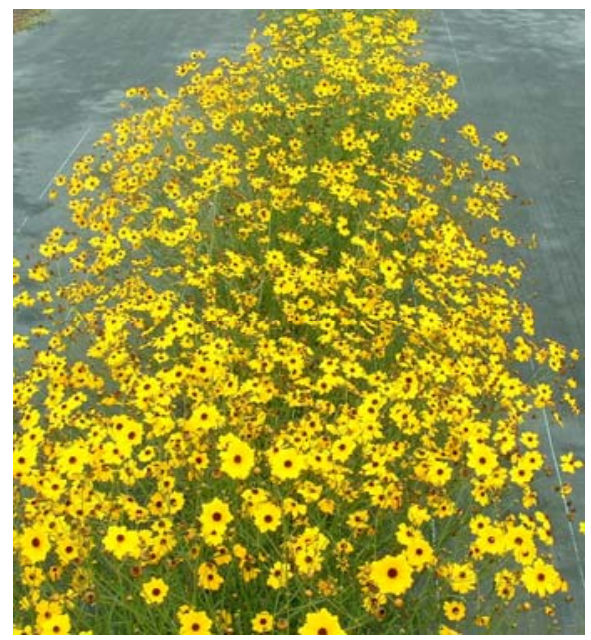

Peak performance occurred on May 30 (Fig. 5). Overall appearance was rated very good to good from mid-May to mid-August. There were 5 or more flowers per plant from May 23 to November 14 (Table 3). Slight insect damage was observed during July and August.

Figure 5. Overall appearance rating ( $1=$ poor to $5=$ excellent $)$ of Coreopsis leavenworthii from April 18 to December 19, 2006.

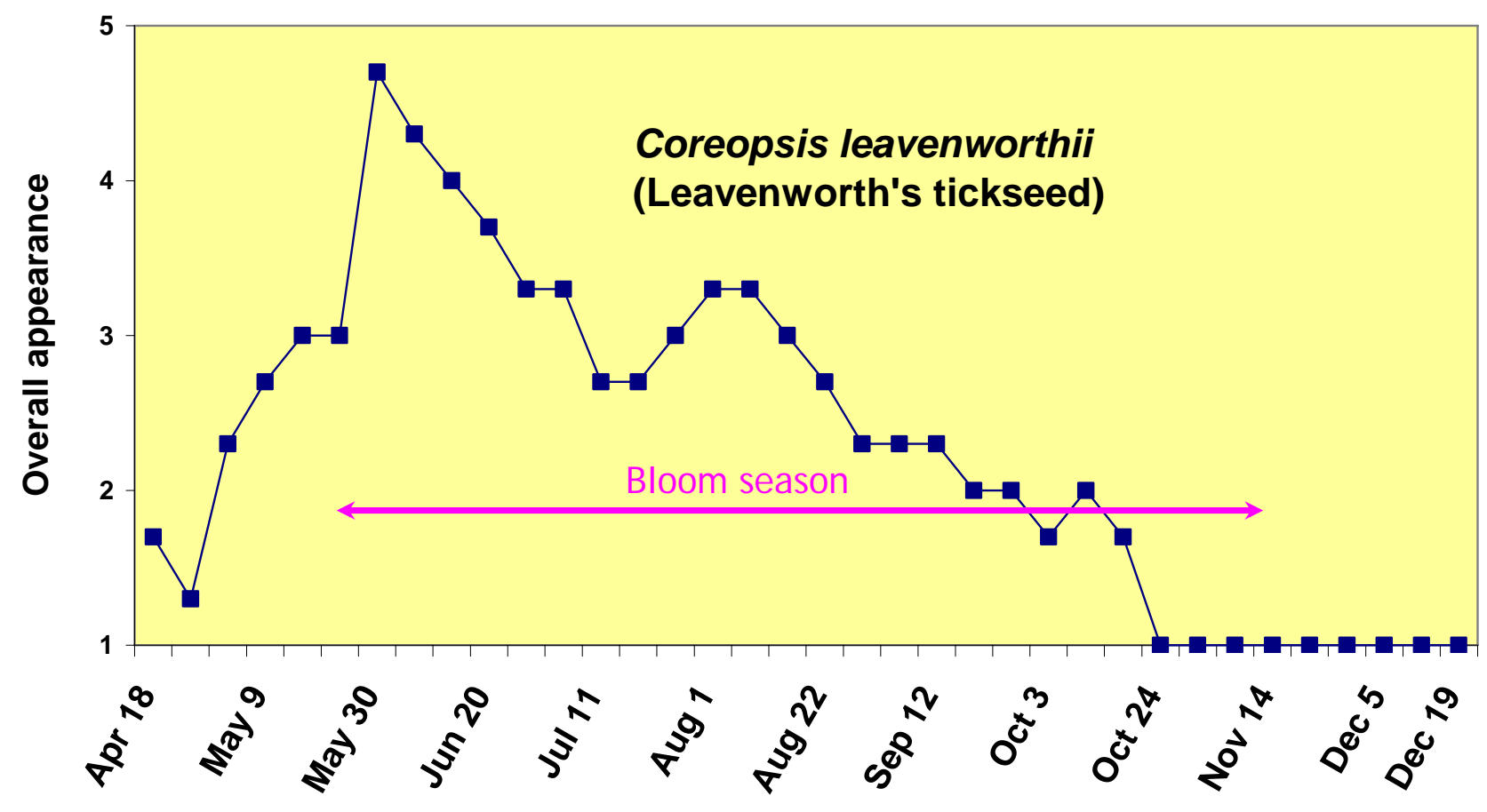




\section{Coreopsis nudata (Georgia tickseed)}

\section{Description - Natural Habitat}

Georgia tickseed, which is locally known as swamp tickseed, is a tall (up to $5 \mathrm{ft}$ ), shortlived perennial to perennial. The local name is appropriate because it occurs along swamp edges and other moist to wet sites with rich soils such as ditches, swales, and pond margins. Its purplish to pinkish ray flowers makes it the only native tickseed of its kind in Florida. All other native ones have yellow ray flowers. This species, which only occurs in north Florida, is often seen flowering in rural, roadside ditches as early as March but as late as June. Leaves also are unique among Florida's native tickseeds in that they are rush-like.

\section{Landscape Performance}

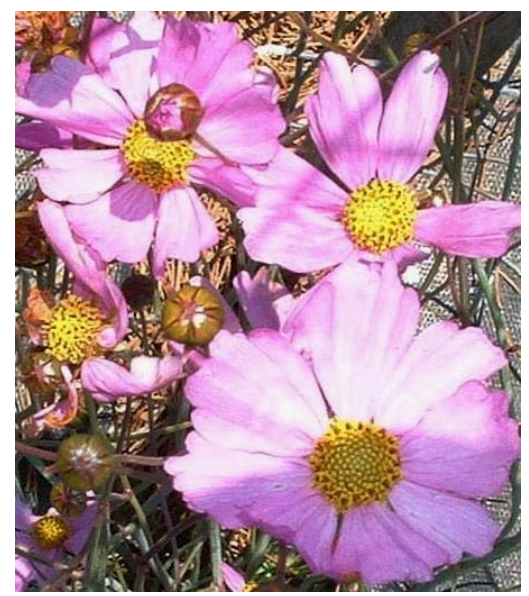

Some plants died after transplanting, with those that survived not rated very highly because none of them flowered. Sometime after July 5, the deer found this tickseed to be very palatable (Fig. 6). The plants never got more than a few inches tall before deer would eat them almost to the soil line. Plants survived this heavy feeding and in December were enclosed in a wire cage to allow them to overwinter. Some minor insect feeding was noted. In the greenhouse, and charcoal rot (Macrophomina phaseolina) has been a problem.

Figure 6. Overall appearance rating ( $1=$ poor to $5=$ excellent $)$ of Coreopsis nudata from April 18 to December 19, 2006.

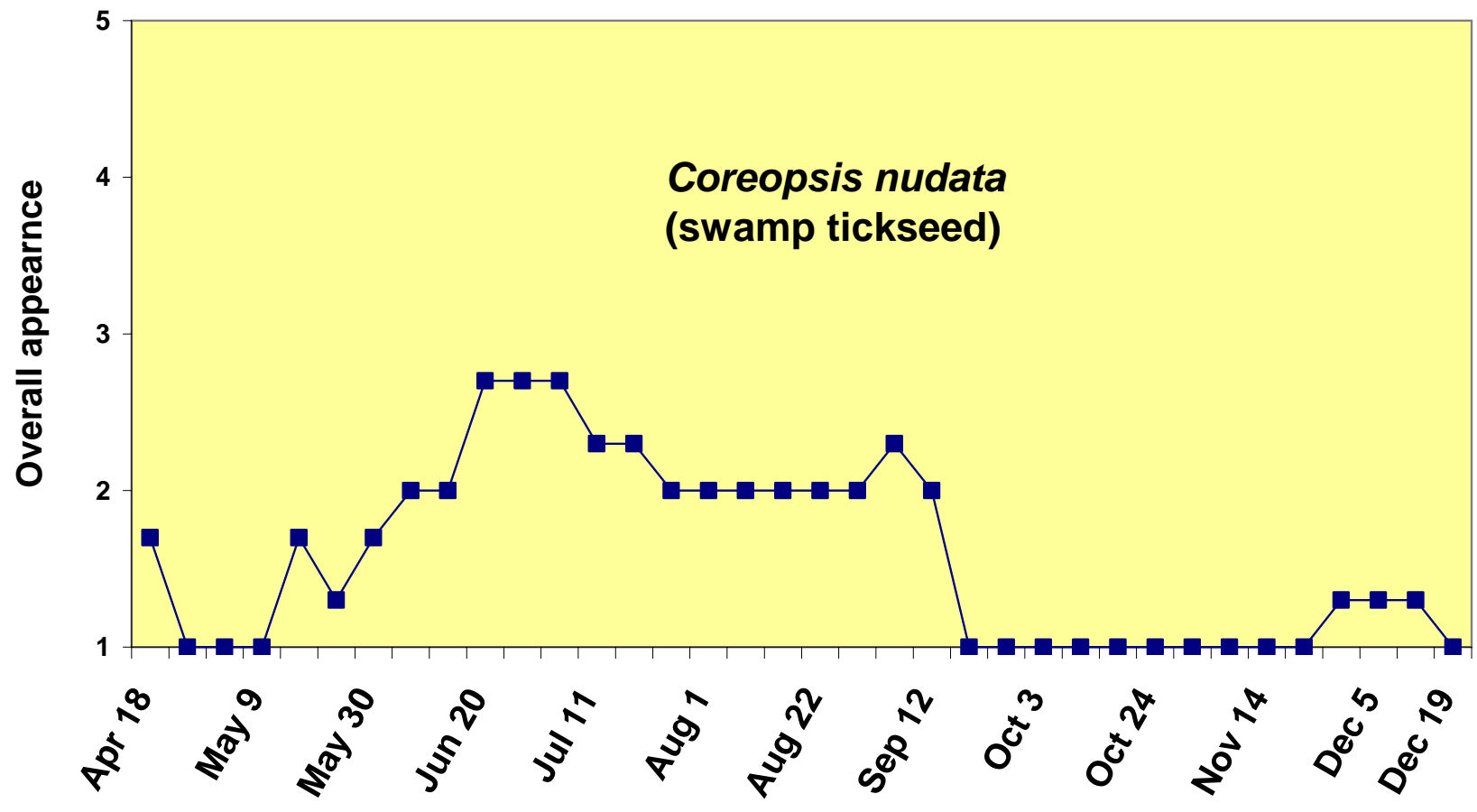




\section{Coreopsis pubescens (star tickseed)}

\section{Description - Natural Habitat}

Star tickseed, like lanceleaf tickseed, is an evergreen to semi-evergreen perennial with yellow ray and disc flowers. Unlike lanceleaf tickseed, it typically blooms in August and September. Star tickseed occurs in only four western panhandle counties and prefers a slightly moist to slightly dry, but well-drained soil.

\section{Landscape Performance}

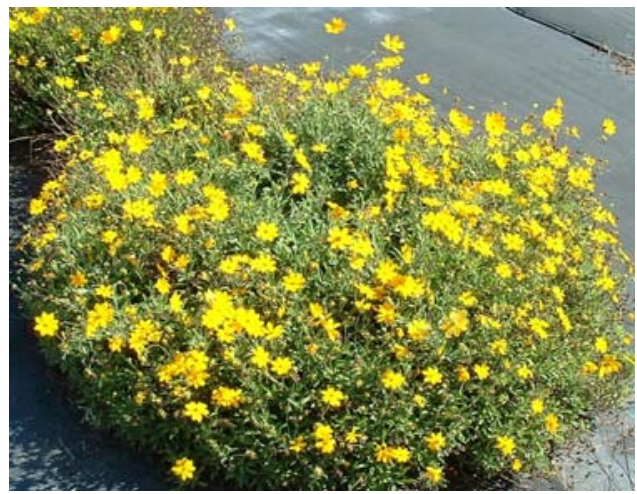

Peak performance was during June (Fig 7). Good overall appearance occurred from mid-May to near the end of November. Noticeable flowering occurred from late May to early December (Table 3). Slight insect damage occurred and was due mainly to chewing insects and thrips. Some disease damage (leaf spot) was noted starting in December.

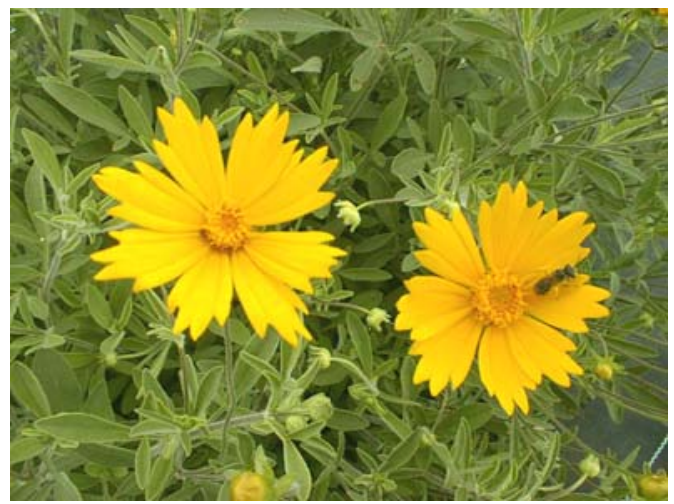

Figure 7. Overall appearance rating ( $1=$ poor to $5=$ excellent $)$ of Coreopsis pubescens from April 18 to December 19, 2006.

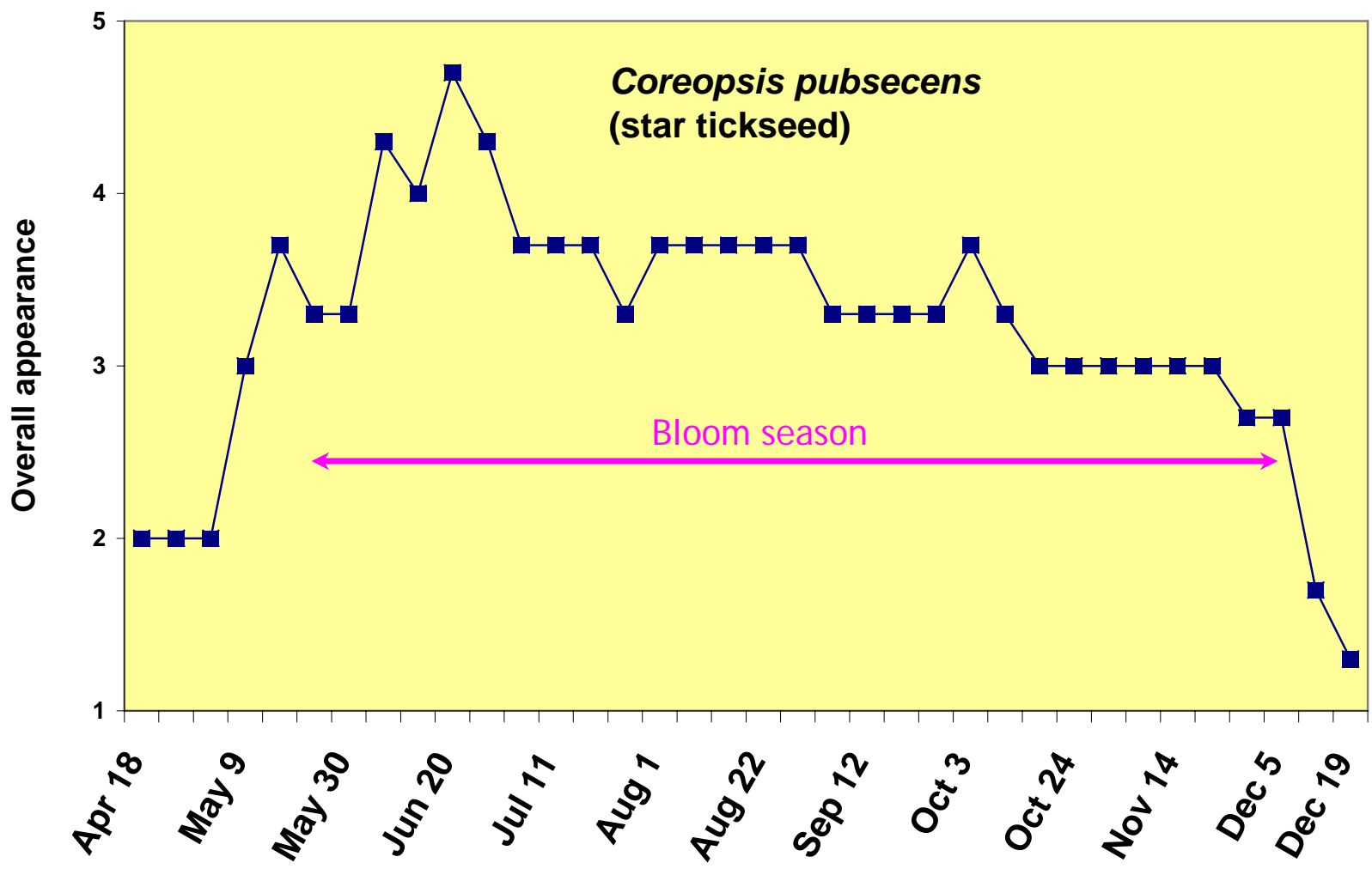




\section{Flaveria linearis (narrowleaf yellowtops)}

\section{Description - Natural Habitat}

Narrowleaf yellowtops is a perennial mainly found in coastal counties of peninsular Florida, with the only documented populations in north Florida in Wakulla and Taylor Counties. It is the only native Flaveria that occurs in the panhandle; a nonnative species, F. bidentis, occurs in Escambia County. Narrowleaf yellowtops typically occurs in moist sites in coastal areas, hammocks, pinelands, and ditches. Flower heads are composed of many small yellow, tubular disc florets; many of the disc florets have a single yellow ray flower. While narrowleaf yellowtops has been observed blooming as early as August, it typically flowers in mid to late fall in north Florida.

\section{Landscape Performance}

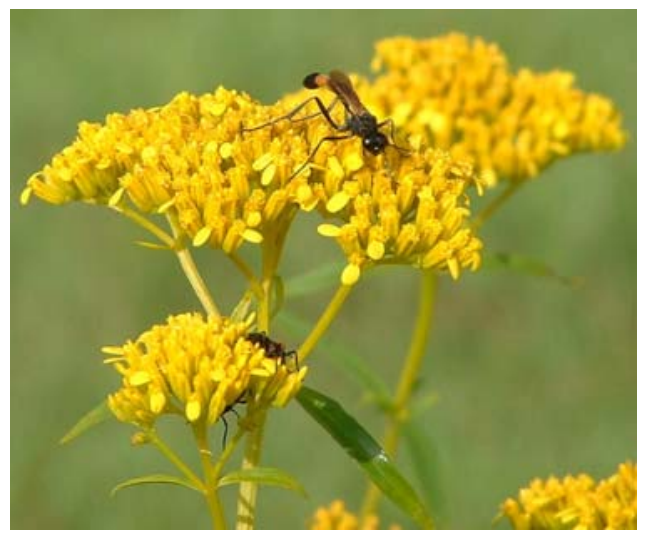

Overall plant appearance was rated good or better from early June to mid-October 17, with plants rated as excellent at the end of August (Fig. 8). Five or more flower heads per plant occurred from July 18 to December 19 (Table 3). By season's end, a single plant was close to $5 \mathrm{ft}$ tall and $6 \mathrm{ft}$ wide. There were insects (possibly a seed beetle) that appeared

on mature seed heads, but their impact was unknown. A minor leaf spot infestation started in mid-October but had no impact on overall appearance.

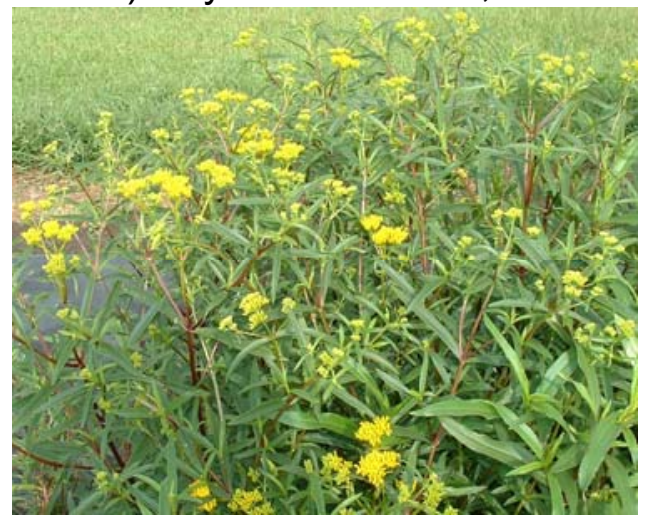

Figure 8. Rating of overall appearance $(1=$ poor to $5=$ excellent $)$ of Flaveria linearis from April 18 to December 19, 2006.

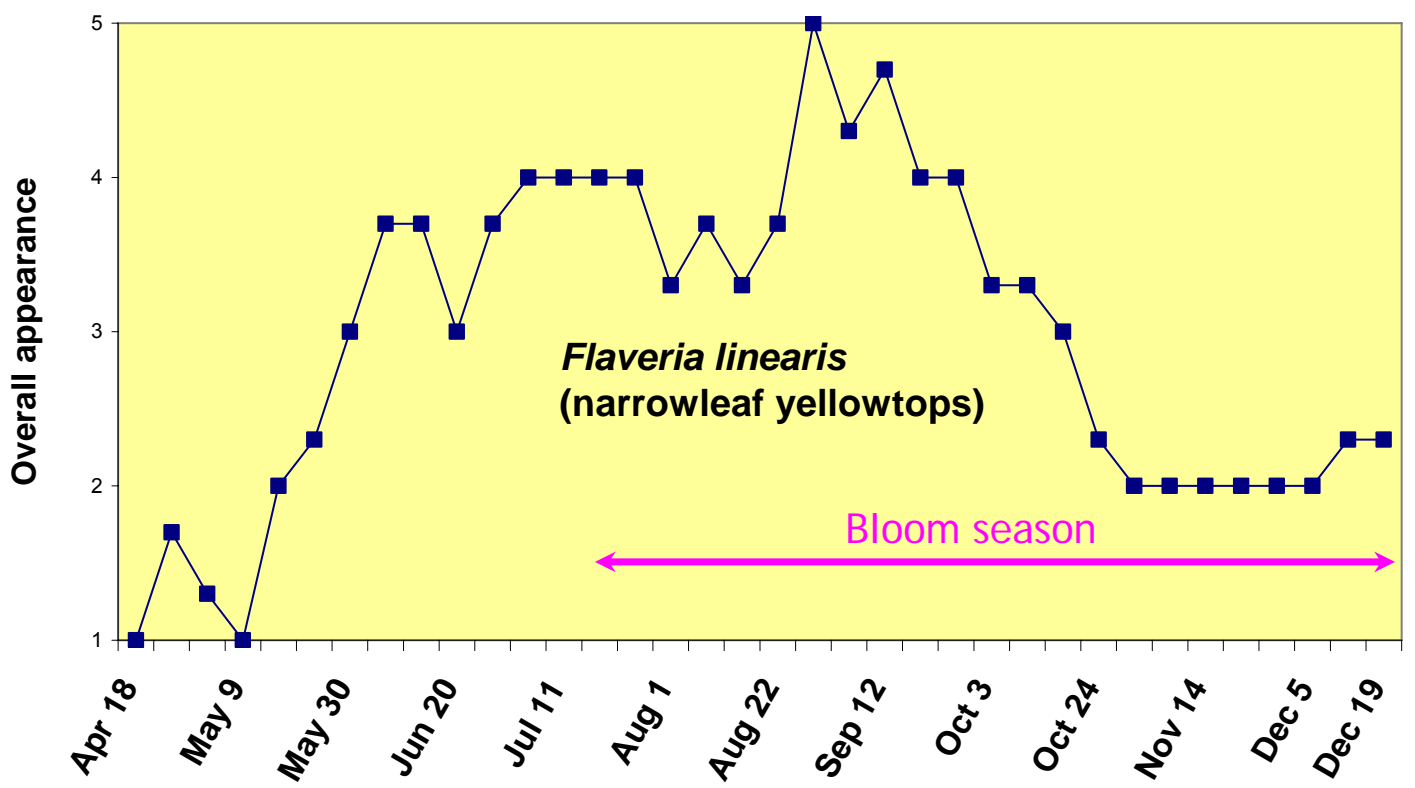




\section{Gaillardia pulchella (firewheel)}

\section{Description - Natural Habitat}

Firewheel, also known as blanketflower and Indian blanket, is an annual to short-lived perennial. While it occurs throughout the state, firewheel only has been documented in about half of Florida's counties. This species is often found in coastal areas. Ray flowers typically have an inner band of red and an outer band of yellow, although the relative amounts can vary substantially to the point that some flowers are solid red or yellow. Occasionally, the yellow in ray flowers is replaced by white, resulting in a rosecolored flower. White flowers have been observed but are very rare. Typically, firewheel flowers from very late spring through early fall in north Florida.

\section{Landscape Performance}

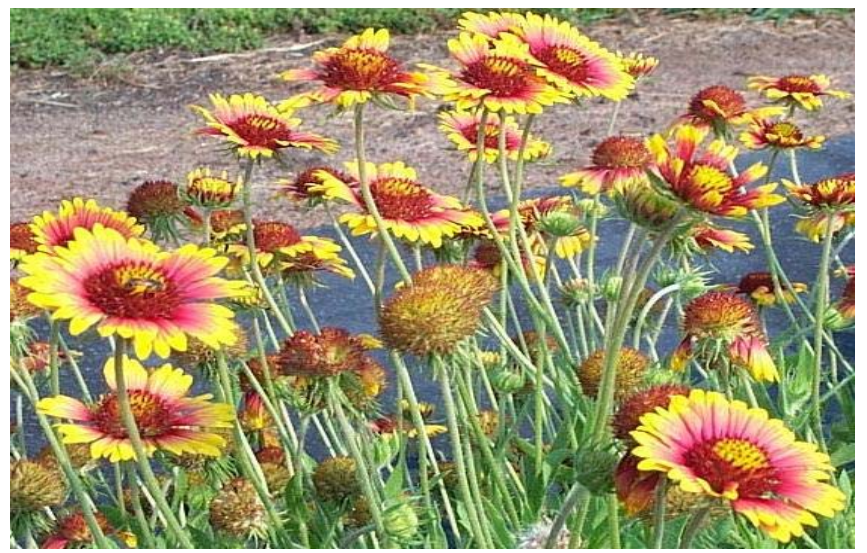

From early May to early December, overall appearance was rated good to excellent, with plants rated very good to excellent for most of the summer (Fig. 9). Five or more flowers per plant occurred from May to December (Table 3). By December, plants were nearly 6 $\mathrm{ft}$ wide and $3 \mathrm{ft}$ tall, which is three times wider and twice as tall compared to plants in the wild. Minor thrips damage to the foliage was observed.

Figure 9. Overall appearance rating $(1=$ poor to $5=$ excellent $)$ of Gaillardia pulchella from April 18 to December 19, 2006.

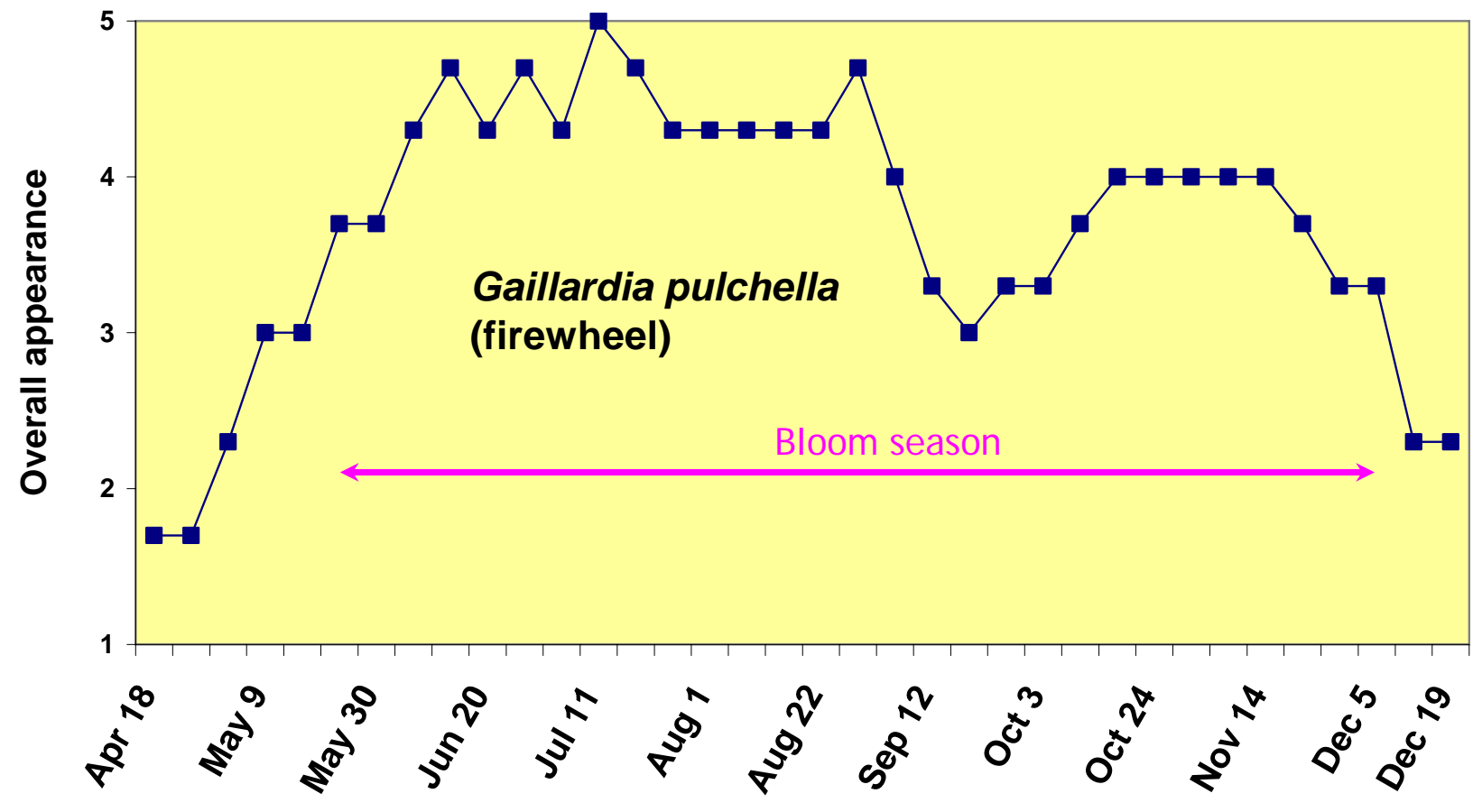




\section{Ipomopsis rubra (standing cypress; Spanish larkspur)}

\section{Description - Natural Habitat}

Standing cypress is listed as a biennial, although we have observed that some plants may be annual to short-lived perennials in north Florida. It mainly occurs in northern peninsular Florida but occurs in Leon and Escambia Counties as well. Standing cypress typically is found in coastal dunes, sandhills, and dry pinelands. Tubular red flowers are borne on upper half of the 2- to 5-ft solitary stems. In north Florida, flowering typically occurs in summer. Multiple shorter stems occur when the growing tip is destroyed by an animal, mowing, etc. The stem has fine, cypress-like foliage, and when not flowering it resembles dogfennel.

\section{Landscape Performance}

From mid-May to mid-November overall appearance was rated as good or better, with peak performance from early August to mid-October (Fig. 10). Some plants had the typical solitary stem, while others were multistemmed. There were 5 or more flowers per plant from August to December (Table 3). Some disease damage was observed in late May and early June. Previously, we noted that standing cypress in north Florida landscape plantings was severely damaged by Fusarium.

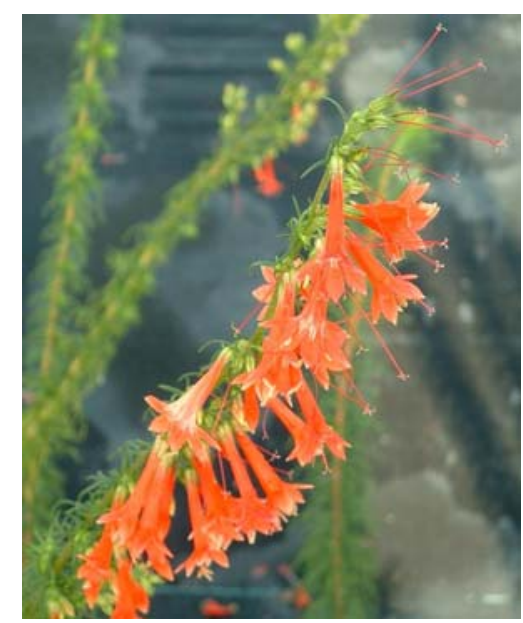

Figure 10. Overall appearance rating ( $1=$ poor to $5=$ excellent) of Ipomopsis rubra from April 18 to December 19, 2006.

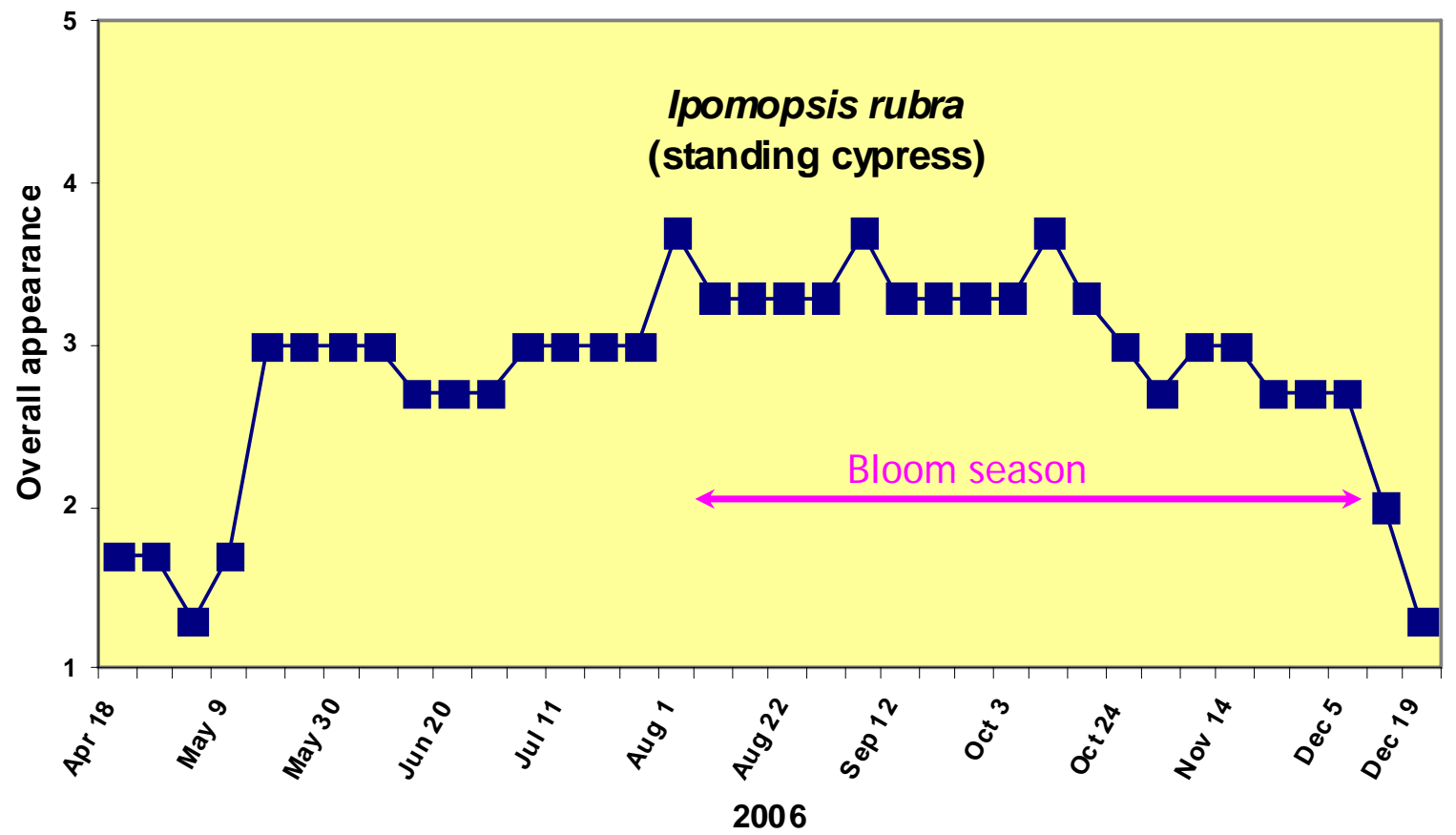




\section{Liatris gracilis (slender gayfeather)}

\section{Description - Natural Habitat}

Slender gayfeather is a perennial found throughout Florida in sandhills or flatwoods. It is a tall upright plant that normally has solitary stems on which an abundance of showy purple flowers are borne in late summer and early fall in north Florida. Taller plants tend to lean to one side or nearly fall over.

\section{Landscape Performance}

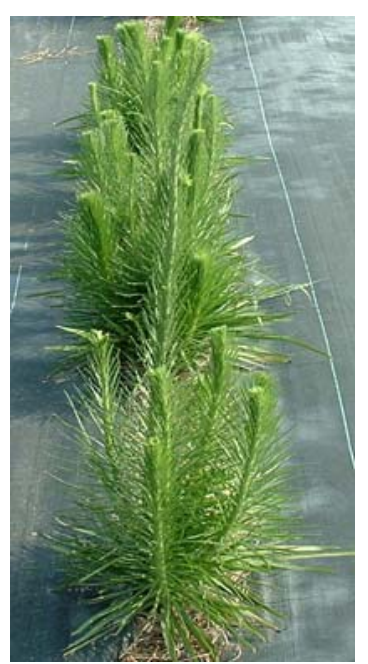

Overall visual appeal was rated good starting in mid-June and continued until early October, with peak performance in mid-September (Fig. 10). The picture on the left illustrates that plants were multi-branched and had relatively dense foliage under landscape conditions. Five or more open flowers per plant occurred from August 29 until October 10 (Table 3). Except for some minor insect damage during establishment, no insect or disease problems were observed.

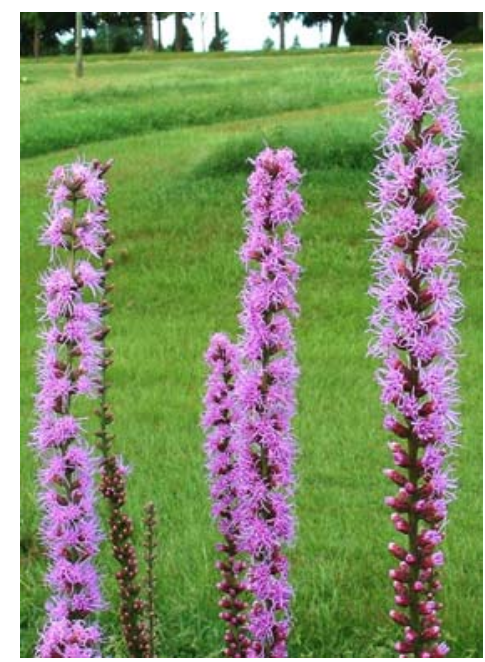

Figure 10. Overall appearance rating ( $1=$ poor to $5=$ excellent $)$ of Liatris gracilis from April 18 to December 19, 2006.

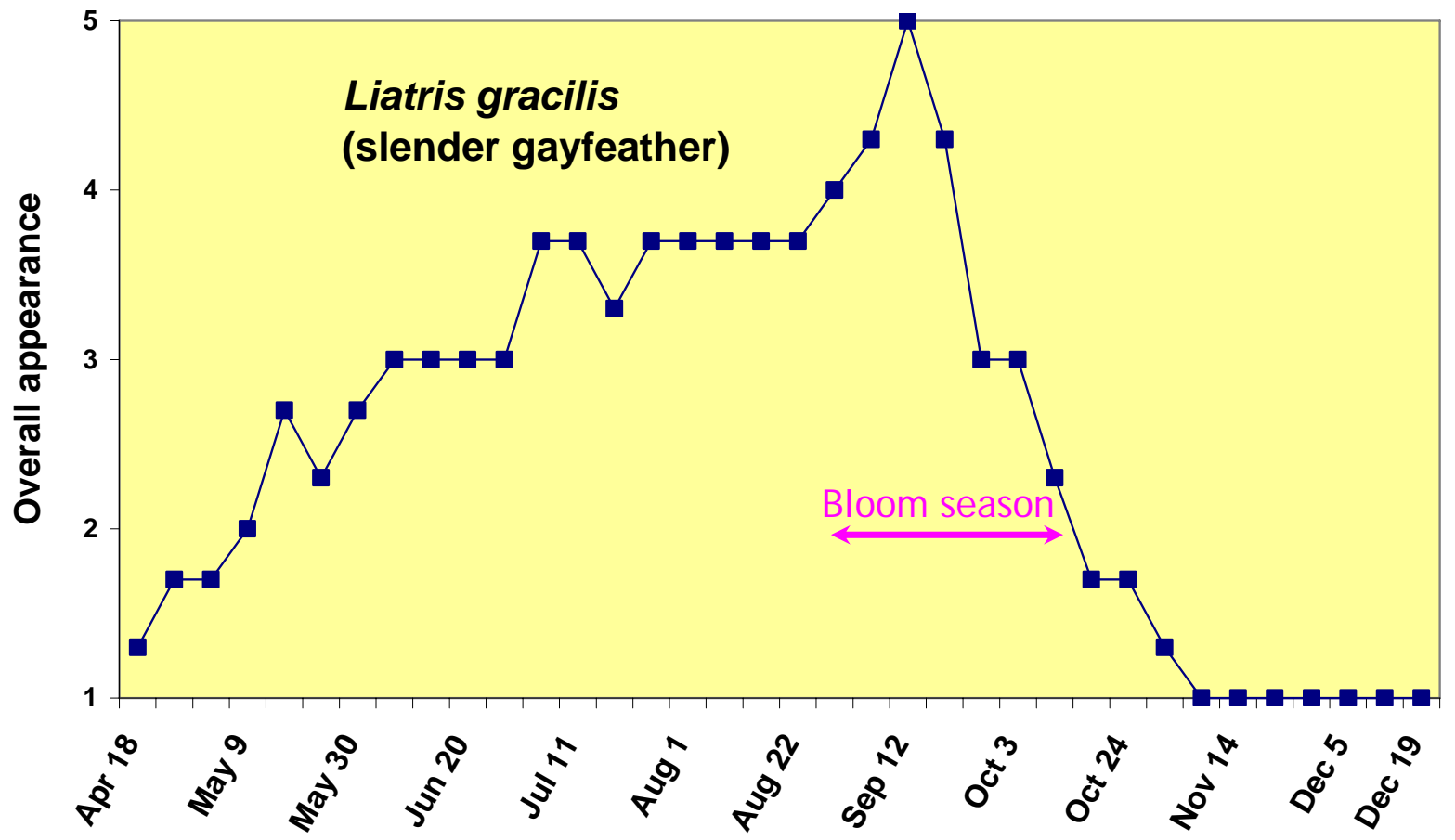




\section{Mimosa strigillosa (powderpuff)}

\section{Description - Natural Habitat}

Powderpuff, also known as sunshine mimosa, is a perennial, mat-forming ground cover.

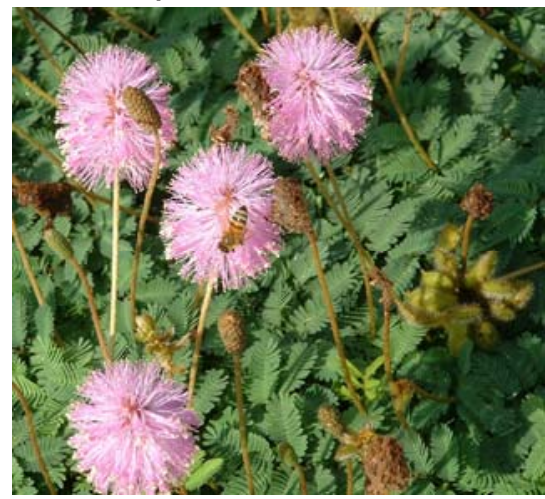
This fine textured legume has stems that become woody over time and are nonprickly (to distinguish it from $M$. quadrivalvis, which has a prickly stem). Distribution in Florida is throughout the peninsula, with the western edge of its range being Leon County. Powderpuff often occurs in disturbed, well-drained sites; its occurrence along roadsides seems to have increased substantially over the past few years. This species, which is aptly named for the shape of its showy purple flowers, typically blooms in May in north Florida.

\section{Landscape Performance}

From the end of May to early November, powderpuff was rated good or better with peak performance during the month of August (Fig. 11). Five or more blooms per plant, which occurred on new growth, were observed from June 27 to December 5 (Table 3). By the end of growing season, the 10 transplants had converged to form a mat that covered nearly $200 \mathrm{sq}$. ft.

Figure 11. Overall appearance rating ( $1=$ poor to $5=$ excellent $)$ of Mimosa strigillosa from April 18 to December 19, 2006.

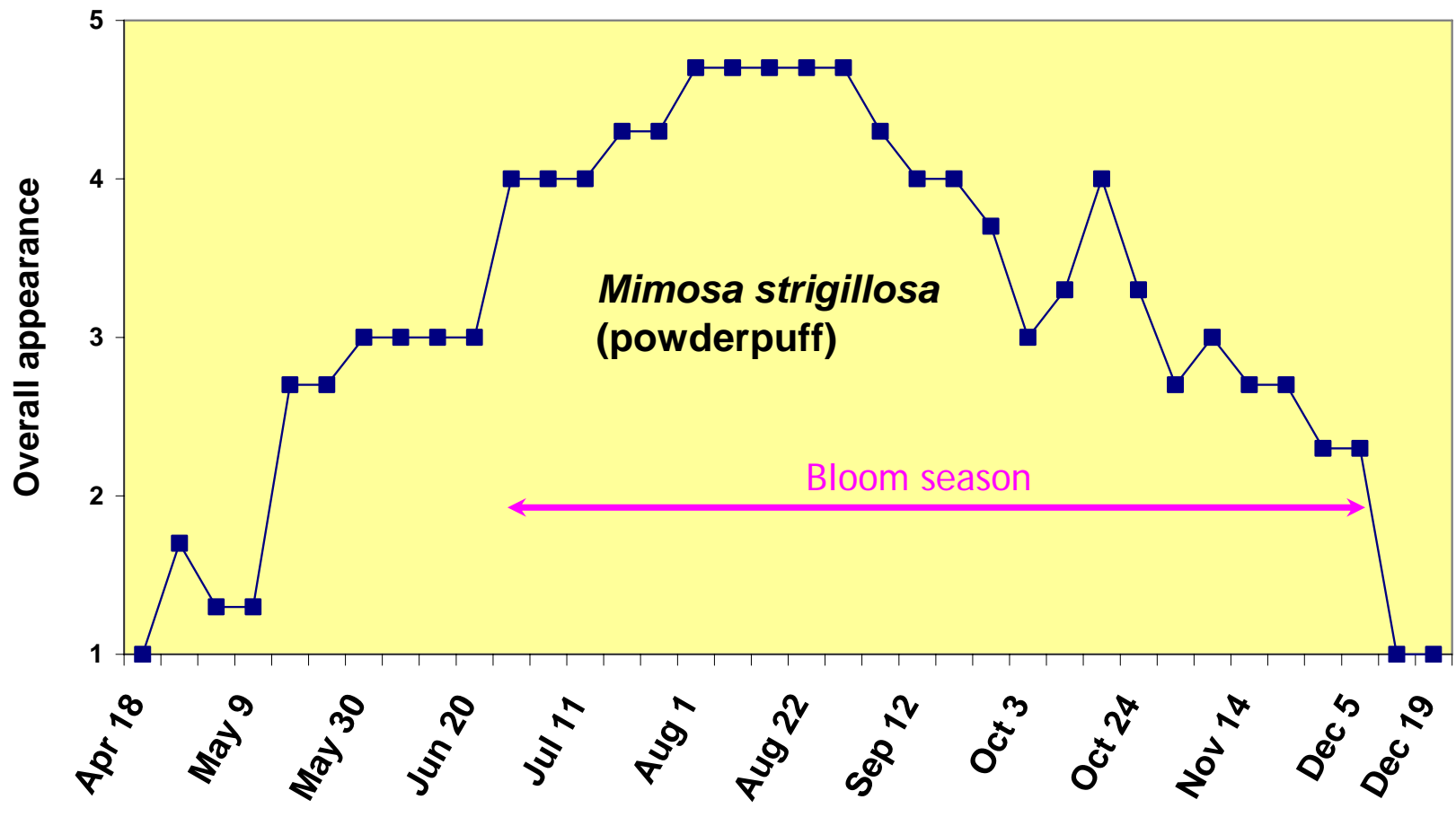




\section{Rudbeckia mollis (softhair coneflower)}

\section{Description - Natural Habitat}

Softhair coneflower is a biennial, although some plants are annual or short-lived perennials. It is most often found growing in dry, sandy sites with well-drained soils in north Florida as far west as Walton County. Disc flowers are dark purple and ray flowers are yellow. This species is appropriately named as both the leaves and upper stems are wooly.

\section{Landscape Performance}

Overall appearance was rated good or better from midJune to early August, with peak performance in early to

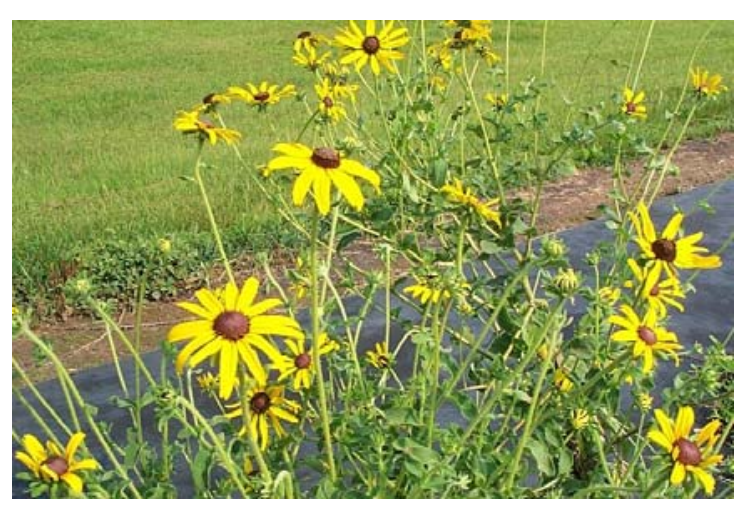

mid July (Fig. 12). Five or more flowers per plant were observed from June 20 to August 29 (Table 3).

Root rot and wind damage

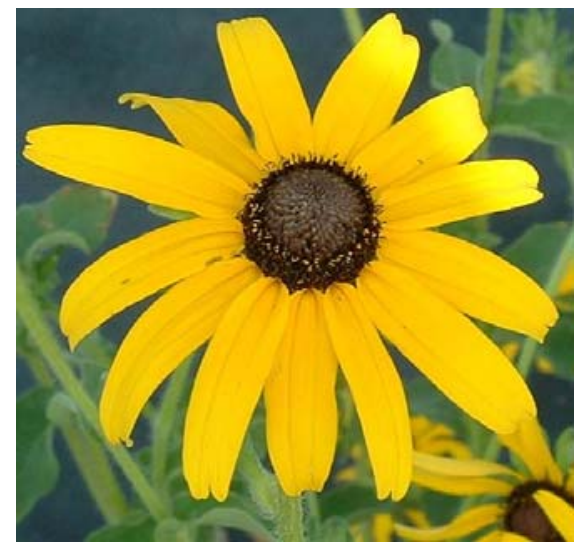
had fully matured. Chewing insects were a minor problem on young plants.

Figure 12. Overall appearance rating ( $1=$ poor to $5=$ excellent) of Rudbeckia mollis from April 18 to December 19, 2006.

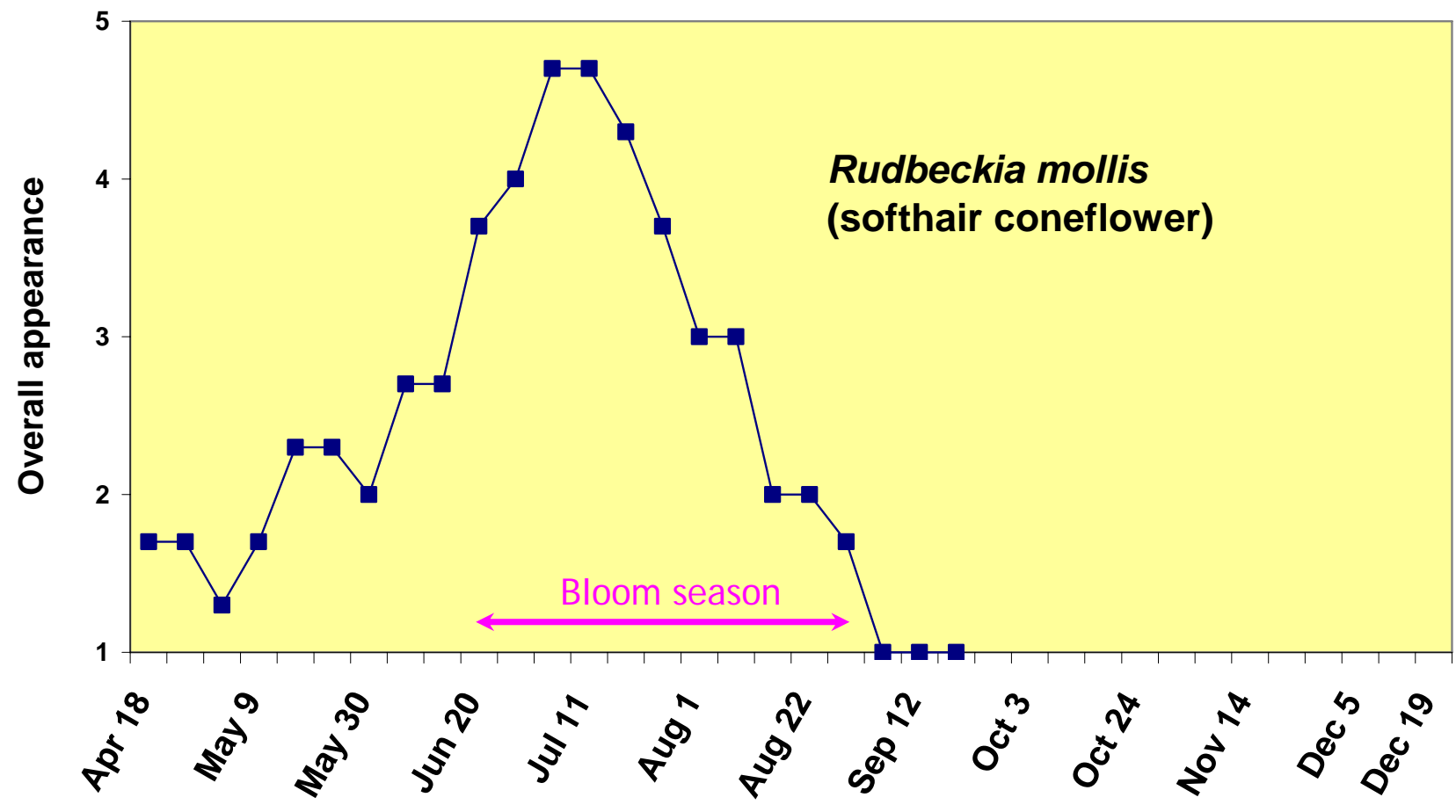




\section{Senna mexicana var. chapmanii (Chapman's wild sensitive plant)}

\section{Description - Natural Habitat}

Chapman's wild sensitive plant is a threatened species in Florida (that is, it's in rapid decline in Florida) found only in pinelands, hammocks, and dunes of Miami-Dade County and the Keys. This perennial legume has yellow orange flowers clustered near the tips of the stems. Typically the flowering season is March to May.

\section{Landscape Performance}

Overall appearance was good or better from the end of June to mid-August (Fig. 13), and again from mid-

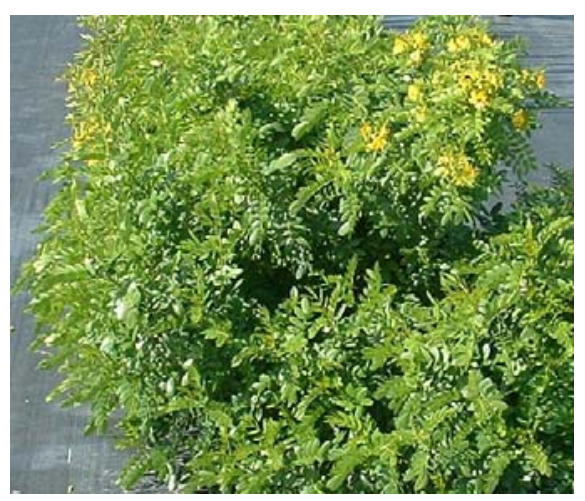
September to midNovember. These ratings mirrored the two blooming seasons we observed (Table 3). In mid-August, sulphur butterfly larvae (see arrow in

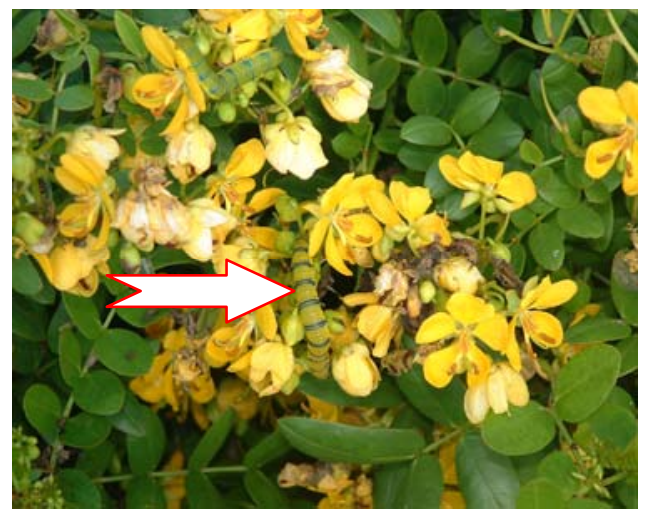
picture on right) were observed feeding on the flowers and foliage, which caused a substantial decline in plant appearance. Sulphur butterfly larvae began feeding again in mid to late October, and by late November plants were decimated.

Figure 13. Rating of overall appearance $(1=$ poor to $5=$ excellent $)$ of Senna mexicana var. chapmanii from April 18 to December 19, 2006.

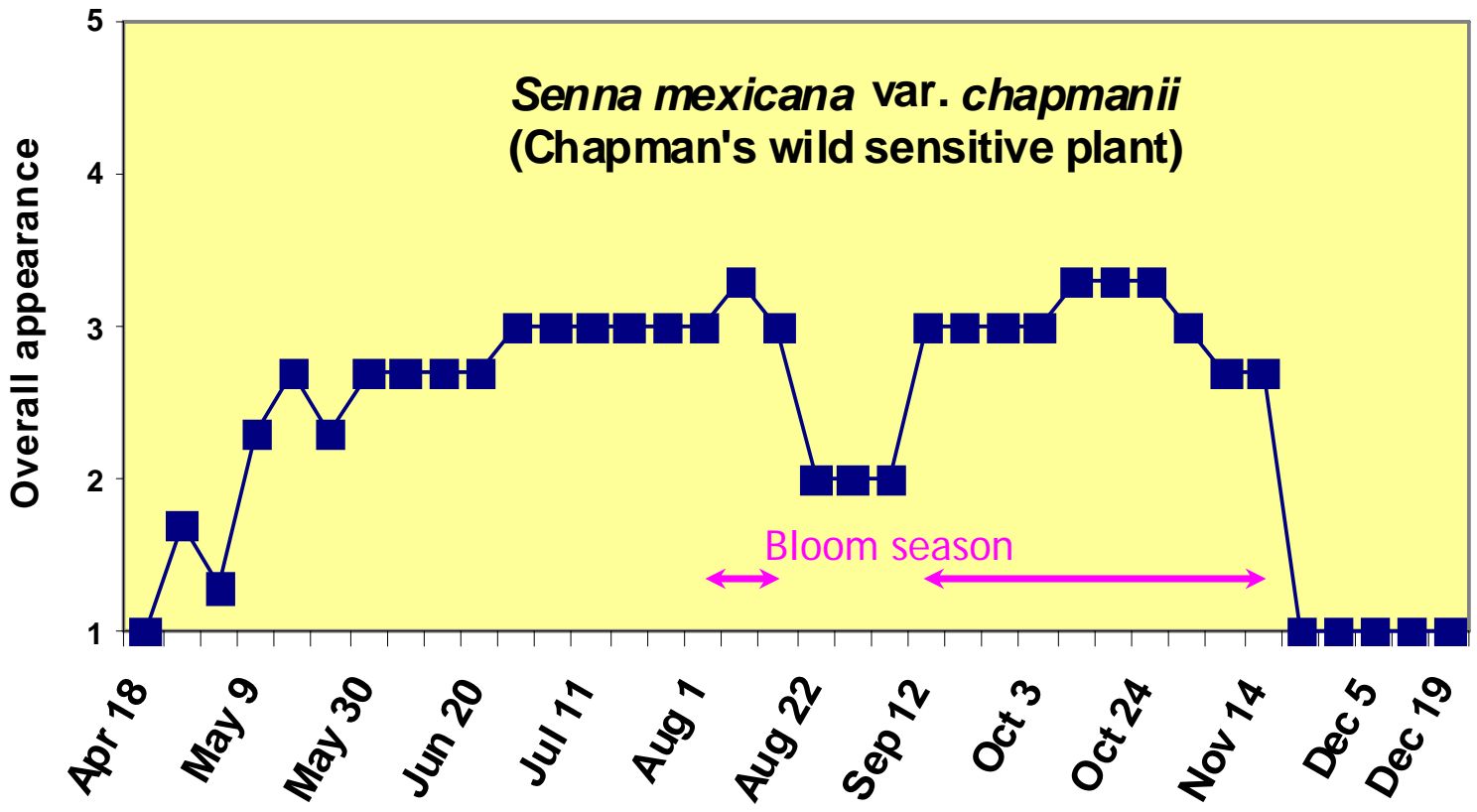




\section{Stokesia laevis (Stokes' aster)}

\section{Description - Natural Habitat}

Stokes' aster is a perennial that is of limited distribution from Escambia to Nassau Counties. It typically grows in partial to full shade in moist soils. The showy purple ray flowers surround the purplish to creamy white disc flowers. Flowering season is from June to August in north Florida.

\section{Landscape Performance}

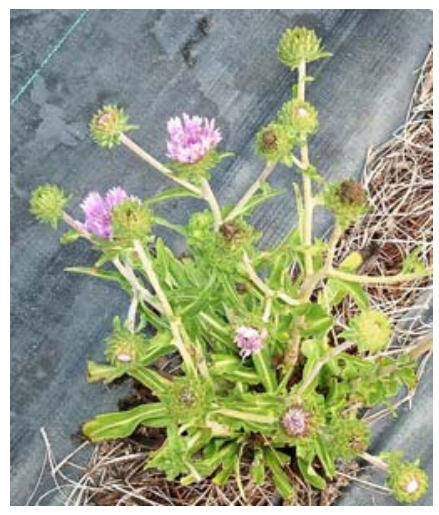

From late June to late July, overall appearance of Stokes' aster was rated as good to very good, with the peak during early to mid-July (Fig.14). Deer browsing caused the decline after July 25 (Fig. 14) and shortened the bloom period to 2 weeks (Table $3)$. Two of the six plants died after transplanting. Only temporary insect damage was apparent. Browning and dieback of a few of the basal leaves were noted from time to time.

Figure 14. Overall appearance rating ( $1=$ poor to $5=$ excellent $)$ of Stokesia laevis from April 18 to December 19, 2006.

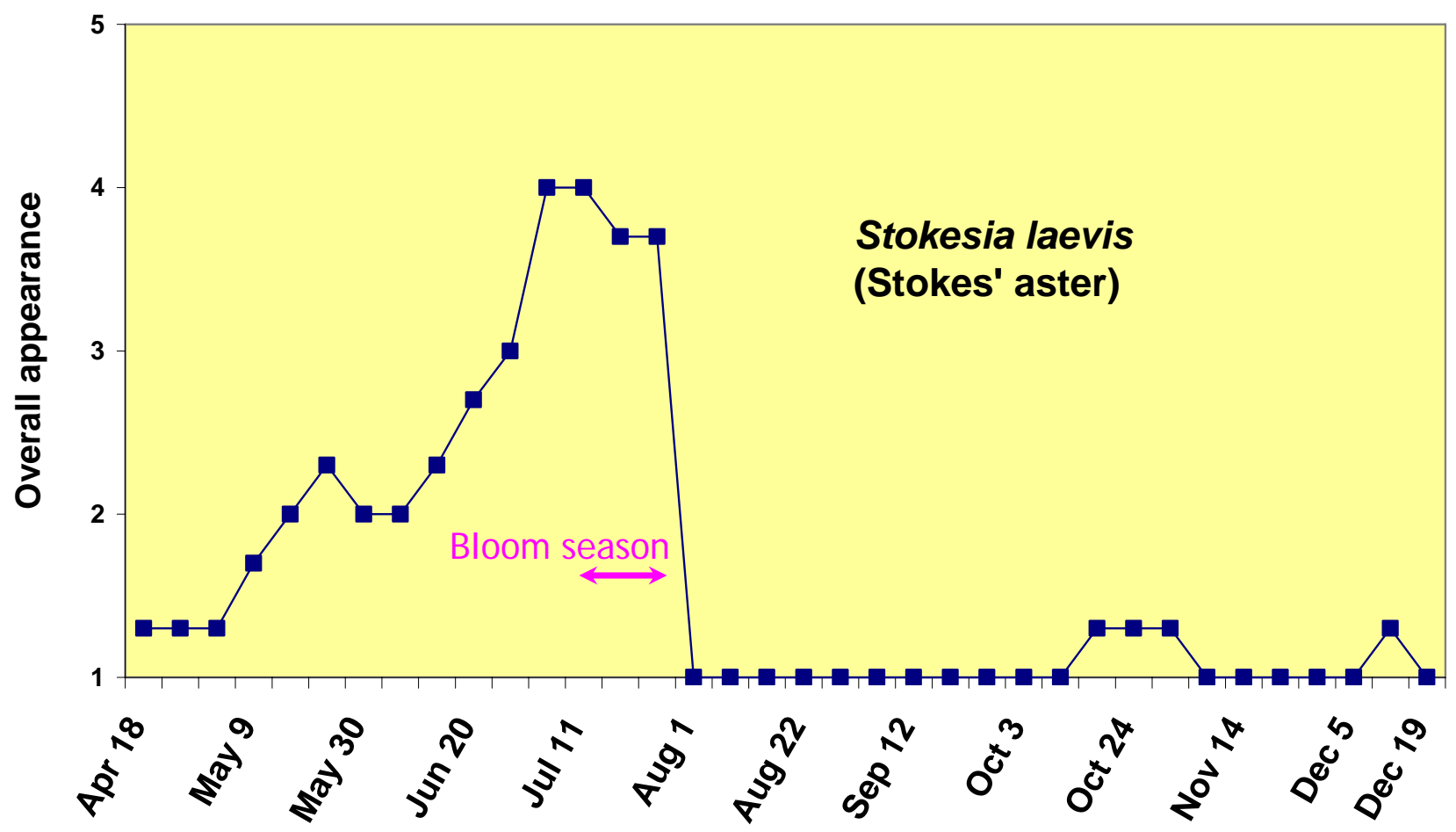




\section{Tridens flavus (tall redtop; purpletop tridens)}

\section{Description - Natural Habitat}

Purpletop tridens was the only grass evaluated. It is a perennial bunch grass with an open habit, sparse foliage, and reddish purple inflorescences. It is found in most counties throughout the state under a wide variety of soil, moisture, and light conditions except full shade.

\section{Landscape Performance}

Purpletop tridens was a much fuller, more densely foliated plant compared to plants in the wild. It was one of the favorites of the evaluators, who rated it good or better from late May to mid-November and excellent during peak flowering in late September (Fig. 15). There was minor insect chewing damage noted early in the evaluation period. Leaf spot was minor and occurred late in the year.

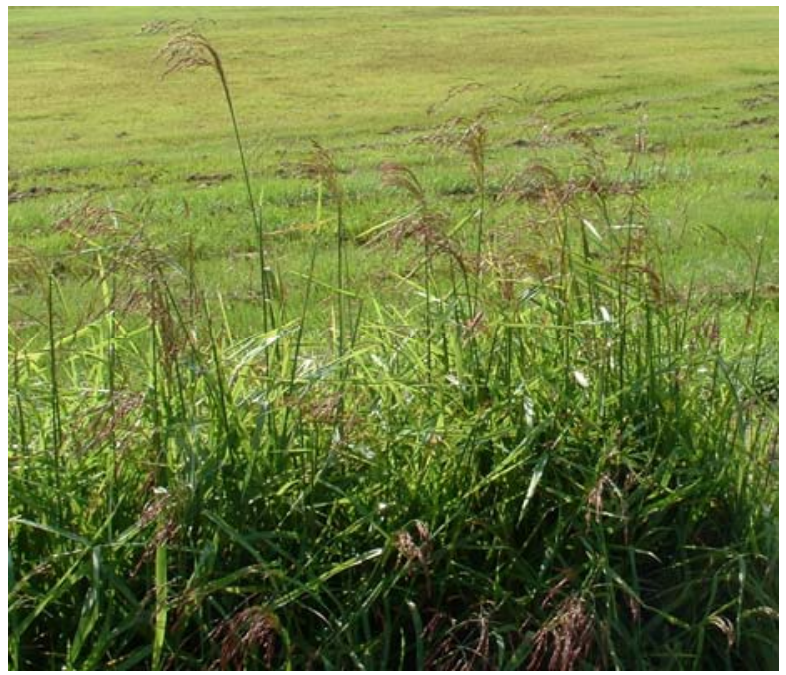

Figure 15. Overall appearance rating ( $1=$ poor to $5=$ excellent) of Tridens flavus from April 18 to December 19, 2006.

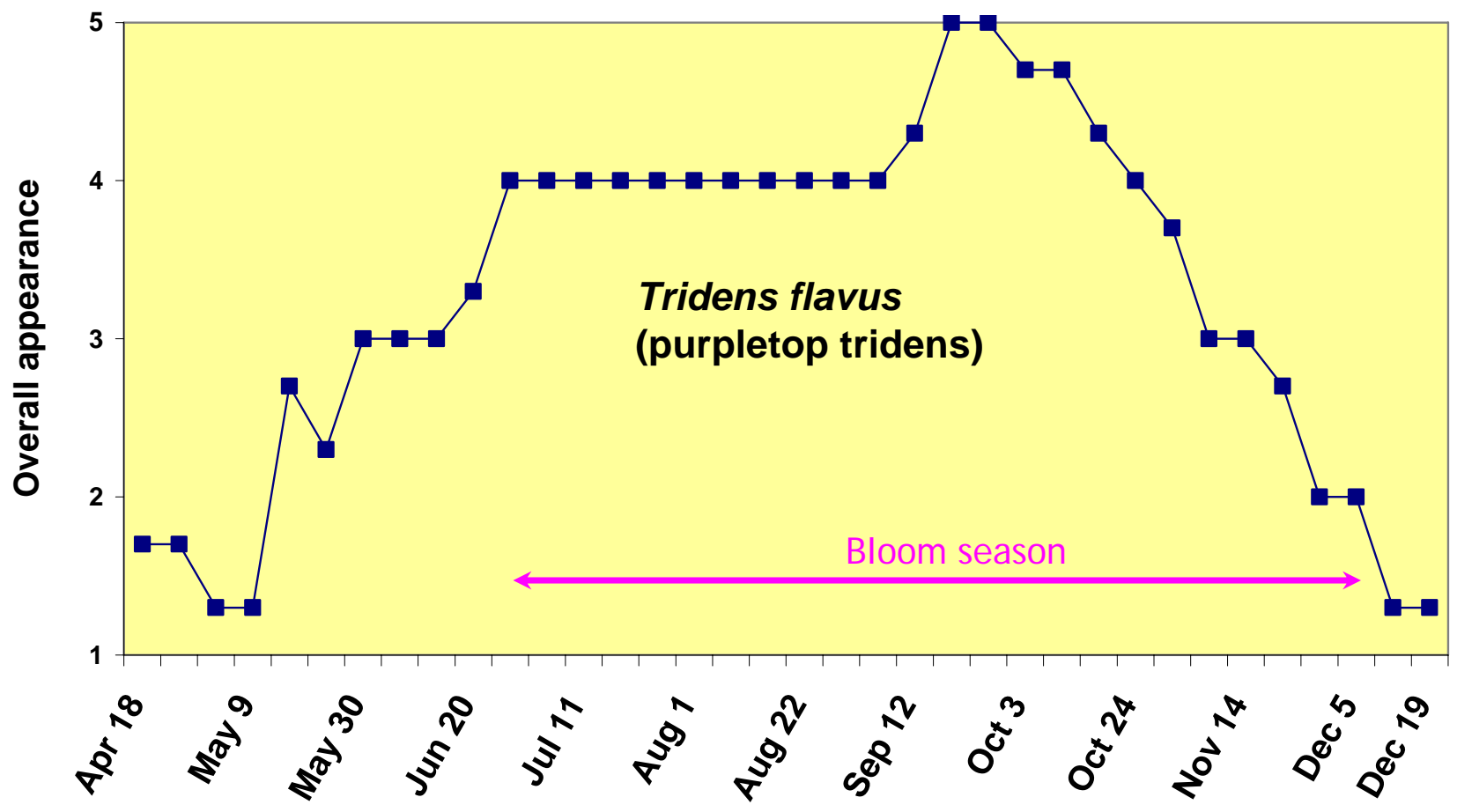


Table 1. Native wildflowers evaluated under landscape conditions at the NFREC-Quincy from April 18 to December 2006.

\begin{tabular}{|c|c|c|c|}
\hline Species name & Common name & $\begin{array}{l}\text { Seed origin; } \\
\text { (state/county) }\end{array}$ & Transplant date \\
\hline Coreopsis floridana & Florida Tickseed & FL; Polk & March 14 \\
\hline $\begin{array}{l}\text { Coreopsis } \\
\text { grandiflora }\end{array}$ & $\begin{array}{l}\text { Largeflower } \\
\text { Tickseed }\end{array}$ & GA; Rockdale & March 14 \\
\hline $\begin{array}{l}\text { Coreopsis } \\
\text { lanceolata }\end{array}$ & Lanceleaf Tickseed & $\begin{array}{l}\text { FL; Wakulla, Leon, } \\
\text { Gadsden, Jefferson }\end{array}$ & March 14 \\
\hline $\begin{array}{l}\text { Coreopsis } \\
\text { leavenworthii }\end{array}$ & $\begin{array}{l}\text { Leavenworth's } \\
\text { Tickseed }\end{array}$ & FL; Orange & March 14 \\
\hline Coreopsis nudata & Georgia Tickseed & FL; Gulf & March 28 \\
\hline $\begin{array}{l}\text { Coreopsis } \\
\text { pubescens }\end{array}$ & Star Tickseed & AL; Dallas & March 14 \\
\hline Flaveria linearis & $\begin{array}{l}\text { Narrowleaf } \\
\text { Yellowtops }\end{array}$ & FL; Indian River & April 4 \\
\hline Gaillardia pulchella & Firewheel & FL; Okaloosa & March 14 \\
\hline Ipomopsis rubra & Standing Cypress & FL; Suwannee & March 14 \\
\hline Liatris gracilis & Slender Gayfeather & FL; Dixie & March 14 \\
\hline Mimosa strigillosa & Powderpuff & FL; Alachua & March 14 \\
\hline Rudbeckia mollis & Softhair Coneflower & FL; county unknown & March 16 \\
\hline $\begin{array}{l}\text { Senna mexicana } \\
\text { var. chapmanii }\end{array}$ & $\begin{array}{l}\text { Chapman's Wild } \\
\text { Sensitive Plant }\end{array}$ & FL; county unknown & March 14 \\
\hline Stokesia laevis & Stokes' Aster & FL; Liberty & March 14 \\
\hline Tridens flavus & Purpletop Tridens & FL; Dixie & March 14 \\
\hline
\end{tabular}

${ }^{1}$ Derived from a composite sample of seeds collected from these counties and subsequently increased in a seed production plot in Monticello, FL. 
Table 2. Temperatures and rainfall at the NFREC in Quincy from April 1 through December 19, 2006.

\begin{tabular}{lccc}
\hline Month & $\begin{array}{c}\text { Avg. max. temp. } \\
\text { (obs. max. temp.) }\left({ }^{\circ} \mathrm{F}\right)\end{array}$ & $\begin{array}{c}\text { Avg. min. temp } \\
\text { (obs. min. temp) }\left({ }^{\circ} \mathrm{F}\right)\end{array}$ & Rain (inches) \\
\hline April & $84(92)$ & $56(39)$ & 1.2 \\
May & $87(96)$ & $61(47)$ & 4.8 \\
June & $92(99)$ & $66(54)$ & 3.3 \\
July & $94(99)$ & $69(60)$ & 3.9 \\
August & $94(97)$ & $72(67)$ & 8.5 \\
September & $87(96)$ & $65(47)$ & 3.6 \\
October & $80(92)$ & $54(35)$ & 2.8 \\
November & $70(82)$ & $45(33)$ & 2.5 \\
December & $68(79)$ & $42(23)$ & 0.8 \\
$(1-19)$ & & & \\
\hline
\end{tabular}


Table 3. Flowering and growth characteristics of native wildflowers evaluated under landscape conditions at the NFREC-Quincy from April 18 to December 19, 2006.

\begin{tabular}{|c|c|c|c|c|c|c|}
\hline \multirow[b]{3}{*}{ Species } & \multirow[b]{3}{*}{$\begin{array}{l}\text { First } \\
\text { open } \\
\text { flower }\end{array}$} & \multirow[b]{3}{*}{$\begin{array}{l}\text { Blooming season } \\
\text { (no. of open } \\
\text { flowers } \geq 5 \text { ) }\end{array}$} & \multicolumn{4}{|c|}{ Peak bloom } \\
\hline & & & \multirow[b]{2}{*}{$\begin{array}{l}\text { Week } \\
\text { of: }\end{array}$} & \multirow[b]{2}{*}{$\begin{array}{l}\text { Inflor. } \\
\text { diameter } \\
\text { (inches) }\end{array}$} & \multicolumn{2}{|c|}{$\mathrm{Ht} / \mathrm{wd}$. (inches) } \\
\hline & & & & & $\begin{array}{l}\text { Veg. + } \\
\text { inflor. }\end{array}$ & $\begin{array}{l}\text { Veg. } \\
\text { growth } \\
\text { only }\end{array}$ \\
\hline $\begin{array}{l}\text { Carphephorus } \\
\text { paniculatus }\end{array}$ & Aug. 29 & Aug. 29 - Oct. 10 & Sep. 12 & 2.1 & $62 / 32$ & $8 / 11$ \\
\hline $\begin{array}{l}\text { Coreopsis } \\
\text { floridana }\end{array}$ & $--^{1}$ & Began Aug. $8^{2}$ & $--^{1}$ & $--^{1}$ & $--^{1}$ & $--{ }^{1}$ \\
\hline $\begin{array}{l}\text { Coreopsis } \\
\text { grandiflora }\end{array}$ & May 3 & May $30-$ Dec. 5 & May 30 & 1.9 & $27 / 43$ & $17 / 37$ \\
\hline $\begin{array}{l}\text { Coreopsis } \\
\text { lanceolata }\end{array}$ & Apr. 25 & May 3 - Dec. 5 & May 30 & 1.4 & $20 / 30$ & $10 / 19$ \\
\hline $\begin{array}{l}\text { Coreopsis } \\
\text { leavenworthii }\end{array}$ & May 9 & May 23 - Nov. 14 & May 30 & 1.3 & $29 / 53$ & $21 / 31$ \\
\hline $\begin{array}{l}\text { Coreopsis } \\
\text { nudata }\end{array}$ & $--^{1}$ & $--^{1}$ & $--^{1}$ & $--^{1}$ & $--^{1}$ & $--^{1}$ \\
\hline $\begin{array}{l}\text { Coreopsis } \\
\text { pubescens }\end{array}$ & May 3 & May 23 - Dec. 5 & Jun. 20 & 1.8 & $18 / 38$ & $15 / 33$ \\
\hline Flaveria linearis & Jun. 20 & Jul. 18 - Dec. 19 & Aug. 29 & 2.4 & $55 / 49$ & $--^{1}$ \\
\hline $\begin{array}{l}\text { Gaillardia } \\
\text { pulchella }\end{array}$ & May 9 & May 23 - Dec. 5 & Jul. 11 & 2 & $29 / 42$ & $24 / 36$ \\
\hline Ipomopsis rubra & Aug. 1 & Aug. 1 - Dec. 5 & Aug. 1 & 0.8 & $44 / 20$ & $36 / 29$ \\
\hline $\begin{array}{l}\text { Mimosa } \\
\text { strigillosa }\end{array}$ & Jun. 27 & Jun. 27 - Dec. 5 & Aug. 1 & 1.1 & $7 / 48$ & $4 / 48$ \\
\hline $\begin{array}{l}\text { Rudbeckia } \\
\text { mollis }\end{array}$ & Jun. 20 & Jun. 20 - Aug. 29 & Jul. 5 & 2.4 & $42 / 27$ & $30 / 27$ \\
\hline $\begin{array}{l}\text { Senna } \\
\text { mexicana var. } \\
\text { chapmanii }\end{array}$ & $\begin{array}{l}\text { Aug. } 1^{3} / \\
\text { Sep. } 12\end{array}$ & $\begin{array}{l}\text { Aug. } 1-\text { Aug. } 14^{3} ; \\
\text { Sep. } 12-\text { Nov. } 14\end{array}$ & Oct. 17 & 4.1 & $23 / 71$ & $27 / 68$ \\
\hline Stokesia laevis & Jul. 5 & Jul. $11-25$ & Jul. 11 & 1.5 & $16 / 12$ & $9 / 10$ \\
\hline
\end{tabular}


Tridens flavus (grass)

Jun. 20

Jun. 27 - Dec. 5

Sep. 19

$\mathrm{N} / \mathrm{A}$

$75 / 59$

$47 / 54$

${ }^{1}$ Data missing due to deer browsing.

${ }^{2}$ Deer browsing precluded determination of flowering season.

${ }^{3}$ Sulphur butterfly larvae feeding in August devastated the plants, but they survived and bloomed again later.

Acknowledgements: Special thanks to volunteers Richard Thompson, JoAnne Gordon, Maribeth Wood, and the NFREC staff including Amanda Brock, Tom Batey, and Emily Wright for assisting with greenhouse plant production, installation, maintenance, and evaluations. Thanks to John Payne, Terry Zinn, Harriet Wright, and other Florida Wildflower seed producers for providing seeds. 